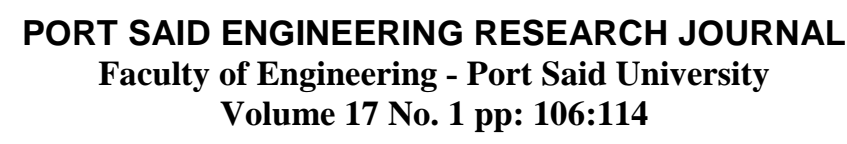

\title{
Experimental Behavior of Concrete Filled Steel Tube Columns
}

\author{
Mohamed Ahmed Mohamedien ${ }^{(1)}$, Mohamed Mohamed El-Ghandour ${ }^{(2)}$, \\ Ibrahim Hassan El-Kersh ${ }^{(3)}$ and Mohamed Ibrahim Hussein ${ }^{(4)}$
}

\begin{abstract}
Concrete filled tube composite columns provide an economic section and fast manufacturing. The concrete infill reduces the initial local buckling of the steel sections which allows very slender steel plates with high values for (width/thickness) ratio to be used in their fabrication. This paper investigates the local and post local buckling behavior of welded box section with and without concrete infill. Thirteen short columns of hollow and filled tube were tested in the concrete research laboratory at Housing and Building National Research Center.
\end{abstract}

\section{INTRODUCTION}

In modern structural constructions, using composite steel-concrete either steel encased in concrete or concrete filled steel tubes become increasingly popular in structural applications like high-rise buildings, bridges, large industrial workshops.

Composite members have better structural performance than that of bare steel or reinforced concrete ones because they have each of reinforced concrete advantages like low material cost; and that of steel like high ductility, high strength-to-weight and stiffness-to-weight ratios and fabric quickNess. Composite columns can also provide an effective solution to many of the problems found in practical design.

In the past, some research results on concrete filled tube composite columns (CFTC), which demonstrated the fact that CFTC columns have generally good performance, and have potential of being used in engineering practice [1-4]. But there is still a lack of information on the CFTC column subjected to axially compression load. It is expected that, due to axial load the behavior of the CFTC column is different from those of hollow steel column. Such a problem has not addressed satisfactorily by design codes. It indicates a need for further research in this area.

The present paper is thus an attempt to study the behavior of concrete filled tube composite (CFTC) columns under axially compression load, the main objectives of this research firstly, to report a series of test results on CFTC column specimens subjected to axial compression load. Secondly, to analyze the influences of several parameters, such as steel wall slenderness (b/t) ratio and infill-concrete compressive strength.

(1) Prof. of steel structure and president of Suez Canal University (SCU), (2) Prof. of steel structure and Dean of Collage of Engineering Portsaid university (PSU), (3) Prof. of steel structure an Dean of Collage of Engineering Suez Canal University (SCU) and (4)

Assistance lecture, Collage of Engineering (SCU).

\section{EXPERIMENTAL PROGRAM}

The experimental program outlines the series of experiments conducted on steel short columns with and without concrete infill. This includes details of pertinent geometric and material properties of experimental work conducted, together with outlining the method of manufacture and testing of specimens and materials. The steel short columns were all fabricated of mild steel plates $3 \mathrm{~mm}$ thickness and welded longitudinally along the full length of columns. Upper and lower head stiffeners were utilized during this fabrication process to minimize initial imperfections [5].

Three sets of tests were conducted; one on hollow steel sections, the second on normal concrete-filled steel tubes and the third set was for high strength concrete-filled steel sections. The concrete-filled steel tubes were loaded on the steel only by virtue of a $20 \mathrm{~mm}$ recess produced at each end. The recess was produced by placing polystyrene at each end during the concrete casting process. The test specimens for the concrete-infill section were also pretreated with oil between the concrete and steel case to ensure that no bond or load transfer to concrete would be developed. The range of slenderness values (b/t) adopted in this test series varying from 41 to 100 , which augments the work conducted by Brain Uy (2001), who considered (b/t) values from 120 to 180. Furthermore, the tests for the hollow sections are significantly greater than the yield slenderness limits designated in international codes. The test specimens including geometric and material properties are summarized in table (1). Furthermore, a typical box section showing the method of fabrication, together with pertinent geometric dimensions is shown in Fig. (1). The general arrangement of the specimen under the machine is shown in Fig.(1). This figure also shows the location of strain gauges used for measuring residual strain, as well as strains during testing. The box sections were also fabricated with end stiffeners which were to ensure that local buckling would occur away from the ends thus avoid an elephant foot failure that would occur at much lower stresses [7-9]. 
Table 1: Summary of test columns configurations

\begin{tabular}{|c|c|c|c|c|c|c|c|c|c|c|c|}
\hline Group & $\begin{array}{l}\text { Specimen } \\
\text { name }\end{array}$ & $\begin{array}{c}\mathbf{b} \\
(\mathbf{m m})\end{array}$ & $\begin{array}{c}\mathbf{t} \\
(\mathbf{m m})\end{array}$ & $\begin{array}{c}\mathbf{L} \\
(\mathbf{m m})\end{array}$ & $b / t$ & $\underset{(\mathbf{m m} 2)}{\mathrm{A}}$ & $\mathbf{L} / \mathbf{b}$ & $L / t$ & $\begin{array}{c}\text { Fy } \\
(\mathbf{M P a})\end{array}$ & $\begin{array}{c}\text { Fu } \\
(\mathbf{M P a})\end{array}$ & $\begin{array}{c}\text { Fcu } \\
(\text { Mpa) }\end{array}$ \\
\hline \multirow{5}{*}{ A } & H1 & 125 & 3 & 650 & 41.67 & 1500 & 5.20 & 216.67 & 243 & 366 & ------- \\
\hline & $\mathrm{H} 2$ & 150 & 3 & 650 & 50.00 & 1800 & 4.33 & 216.67 & 243 & 366 & ------- \\
\hline & H3 & 200 & 3 & 650 & 66.67 & 2400 & 3.25 & 216.67 & 243 & 366 & ------- \\
\hline & $\mathrm{H} 4$ & 250 & 3 & 650 & 83.33 & 3000 & 2.60 & 216.67 & 243 & 366 & ------- \\
\hline & H5 & 300 & 3 & 650 & 100.00 & 3600 & 2.17 & 216.67 & 243 & 366 & ------- \\
\hline \multirow{5}{*}{ B } & F-N1 & 125 & 3 & 650 & 41.67 & 1500 & 5.20 & 216.67 & 243 & 366 & 24.3 \\
\hline & F-N2 & 150 & 3 & 650 & 50.00 & 1800 & 4.33 & 216.67 & 243 & 366 & 24.3 \\
\hline & F-N3 & 200 & 3 & 650 & 66.67 & 2400 & 3.25 & 216.67 & 243 & 366 & 24.3 \\
\hline & F-N4 & 250 & 3 & 650 & 83.33 & 3000 & 2.60 & 216.67 & 243 & 366 & 24.3 \\
\hline & F-N5 & 300 & 3 & 650 & 100.00 & 3600 & 2.17 & 216.67 & 243 & 366 & 24.3 \\
\hline \multirow{3}{*}{$\mathrm{C}$} & F-H1 & 125 & 3 & 650 & 41.67 & 1500 & 5.20 & 216.67 & 243 & 366 & 72.8 \\
\hline & F-H2 & 200 & 3 & 650 & 66.67 & 2400 & 3.25 & 216.67 & 243 & 366 & 72.8 \\
\hline & F-H3 & 300 & 3 & 650 & 100.00 & 3600 & 2.17 & 216.67 & 243 & 366 & 72.8 \\
\hline
\end{tabular}

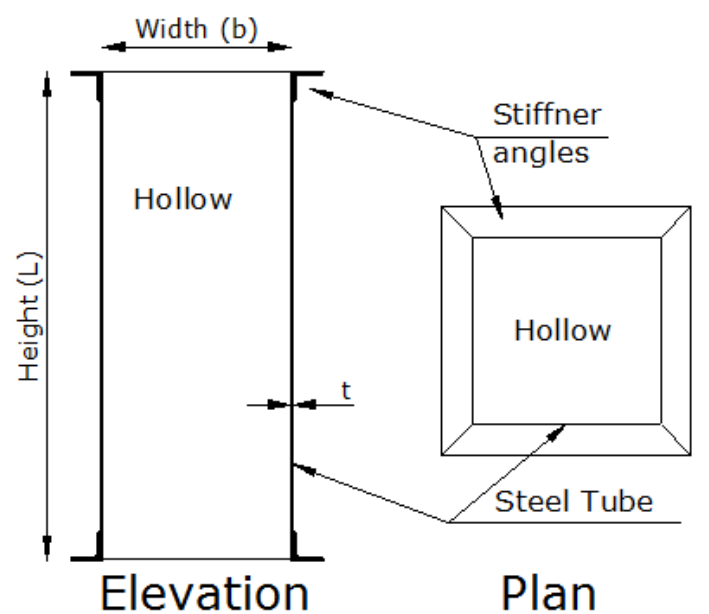

Fig. 1.a Schematic for test specimens of group A

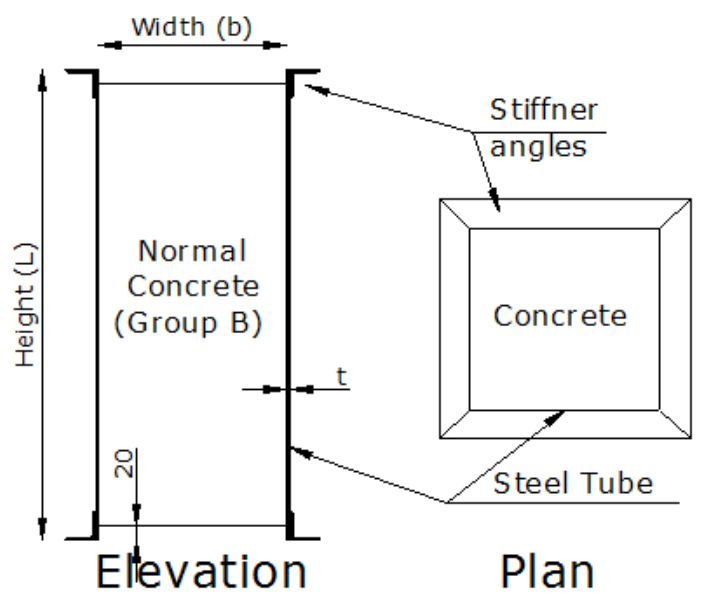

Fig. 1.b Schematic for test specimens of group B

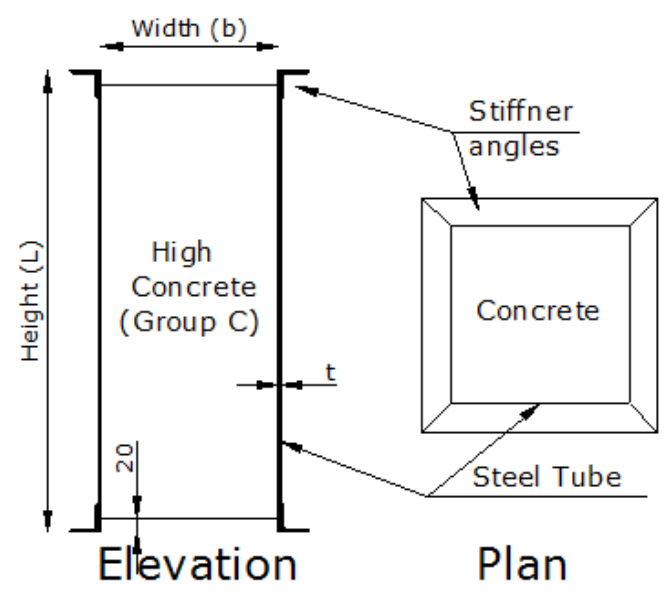

Fig. 1.c Schematic for test specimens of group C

\section{MATERIAL PROPERTIES}

Test Specimens used in the experimental study were manufactured using locally available materials.

\subsection{Concrete}

There were tensile coupon tests conducted to ascertain the stress-strain characteristics. Concrete material properties were concluded in previous researches to be unimportant as they were used merely as a restraint against local buckling and the concrete itself was unloaded, but at this paper, concrete strength was taken into consideration. There are two groups of concreteinfill steel tubes. Cylinder and cubic tests were carried out to ascertain the concrete-infill ultimate strength; the nominal concrete strength was $24.3 \mathrm{MPa}$ and $72.8 \mathrm{MPa}$ at the second group (Group B) and the third group (Group C) respectively that consisted of five columns FN1, FN2, FN3, FN4 AND FN5 were filled with normal plain concrete with concrete face recess $20 \mathrm{~mm}$ at top 
and bottom of steel case edge to prevent any direct normal load transfer to concrete infill.

\subsection{Steel}

A series of 5 steel tensile coupons were tested and the results of these tests are summarized in table (2). The mean yield stress determined from this series of tests was $243 \mathrm{MPa}$ and the mean ultimate stress was 366 $\mathrm{MPa}$. A typical stress-strain curve for these tests is shown in fig. (2), which highlights the ductile nature of mild structural steel.

Table 2: tensile coupons test results

\begin{tabular}{|c|r|r|r|c|}
\hline No. & $\begin{array}{c}\text { Fy } \\
(\mathrm{MPa})\end{array}$ & $\begin{array}{c}\mathrm{Fu} \\
(\mathrm{MPa})\end{array}$ & $\begin{array}{c}\text { Poisson } \\
\text { ratio }\end{array}$ & $\mathrm{E}(\mathrm{Mpa})$ \\
\hline 1 & 251 & 379 & 0.33 & $2.18 \mathrm{E}+05$ \\
\hline 2 & 254 & 364 & 0.3 & $2.15 \mathrm{E}+05$ \\
\hline 3 & 239 & 355 & 0.28 & $2.10 \mathrm{E}+05$ \\
\hline 4 & 240 & 383 & 0.35 & $2.32 \mathrm{E}+05$ \\
\hline 5 & 231 & 349 & 0.26 & $1.85 \mathrm{E}+05$ \\
\hline Mean & 243 & 366 & 0.304 & $2.12 \mathrm{E}+05$ \\
\hline
\end{tabular}

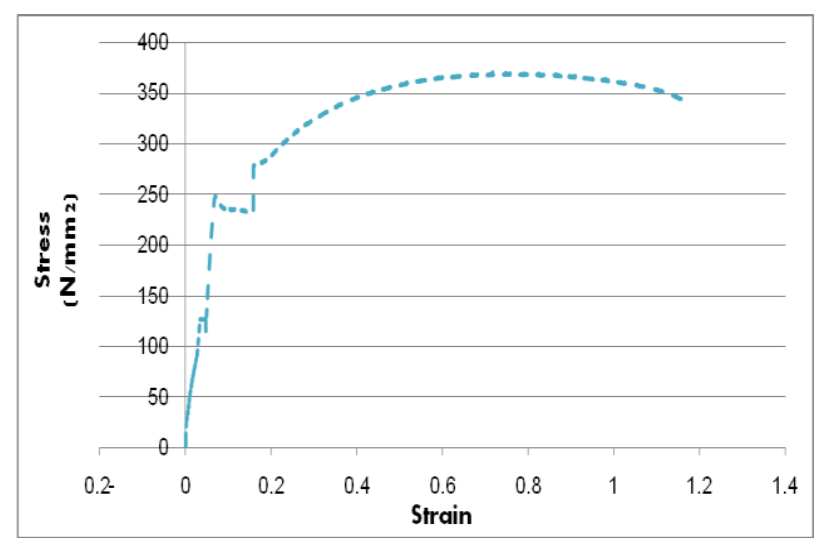

Fig. 2: stress strain curve of steel material

\section{MANUFACTURING}

\subsection{Box steel sections}

All of the thirteen stub columns were manufactured from high graded steel sheets $3 \mathrm{~mm}$ in thickness. Two plates were cut from the sheet to be as L shape. The prepared plates were tack welded into square shape with a single bevel butt weld. Strips of steel plate were tested in tension. Five coupons were taken from steel plates. The average yield strength, ultimate tensile strength, modulus of elasticity and Poisson`s ratio are shown it table 3.12. All box sections were also fabricated with end stiffeners which were to ensure that local buckling would occur away from the ends and thus avoid an elephant foot failure that would occur at much lower stresses.

\subsection{Mixing of Concrete}

A mechanical mixer was used to mix the concrete constituents; the period of mixing was about 3 minutes. Cement, sand, and dolomite were first dry mixed for about one minute until a homogeneous color for the mix was observed. Then, the water was gradually added while the mixing was in process and continued for 2 minutes, until concrete mix of suitable consistency was obtained. The consistency of the concrete mix was checked by the "Slump Test" using a truncated cone of $305 \mathrm{~mm}$ high, 101/203 $\mathrm{mm}$ variable diameter. The average slump value was $80 \mathrm{~mm}$.

\subsection{Casting test specimens}

The concrete-filled steel sections were loaded on the steel only by virtue of a $20 \mathrm{~mm}$ recess produced at each end. The recess was produced by placing polystyrene at each end during the casting process. Also all box sections were pretreated with grease between the concrete and steel, thus ensuring that no bond and no load transfer to the concrete would be developed. Box sections were filled with concrete in layers using a vibrator for compaction. In order to ensure the compaction of concrete, the maximum height of each layer was kept about $0.25 \mathrm{~m}$, and the interval of filling was about $3 \mathrm{~min}$ for maximum air emitting from the concrete during consolidation process. The specimens were placed upright to air-dry. After 24 hours all casted specimens were taken to a water pool for concrete curing.

\section{TEST SETUP}

Thirteen columns have been carried out in the concrete research laboratory at Housing and Building National Research Center. The tested columns were transported into the laboratory using special manual truck and suspended jack, shown in Fig. (3.a). Before testing, strain gauges were glued on the steel plate's surface, shown in Fig. 3.C. The columns were then placed and adjusted into position on the machine, shown in Fig. 3.b.

\subsection{Loading}

The load was applied using universal testing machine of $5000 \mathrm{kN}$ overall capacity. The machine has reading range increments start with $200 \mathrm{kN}, 500 \mathrm{kN}$, up to 2000 $\mathrm{kN}$. For all short columns testing processes, the $500 \mathrm{kN}$ range was chosen. Readings for strains and deflections were recorded continuously. The process of column loading was continued up to failure 


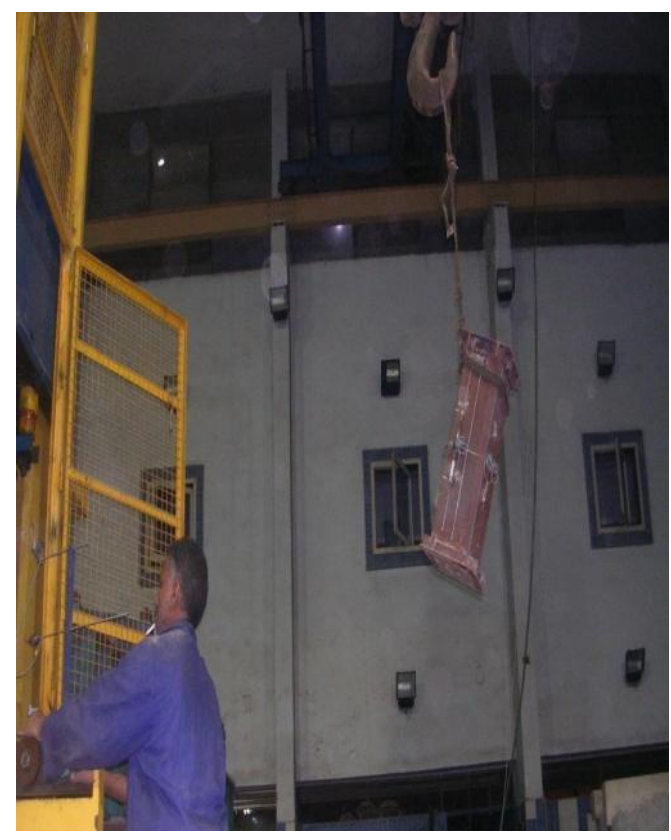

Fig. 3.a Transportation of specimens

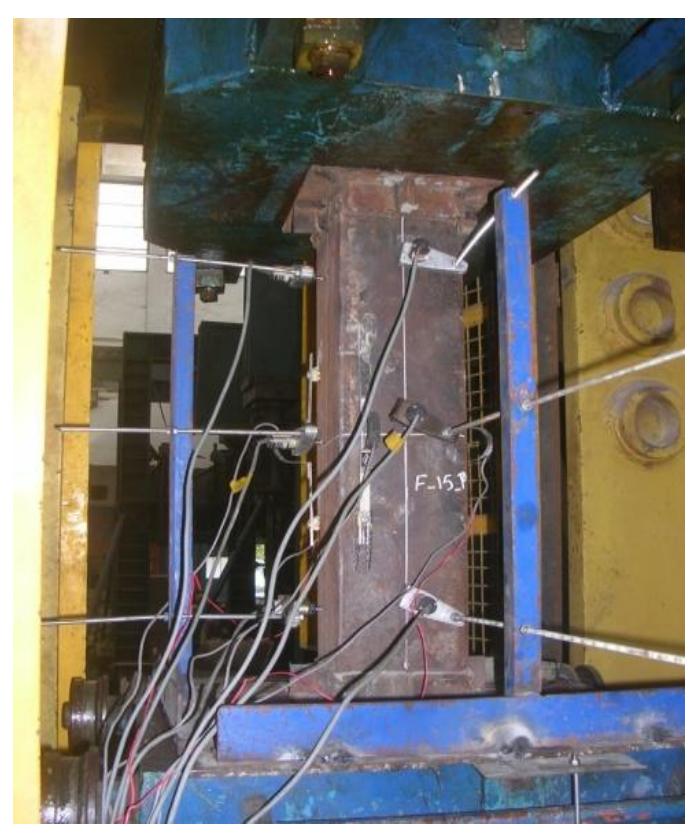

Fig. 3.b Setup of specimens and measurement

\subsection{Measurements}

Two strain gauges were used for each specimen to measure strain at the middle height. One linear variable displacement transducer (LVDT) was used to measure the axial deformation .

Six LVDTs were used to measure lateral displacement at middle height and at top and bottom third height. Four Bi gauges were fixed at middle height at each side to measure the strain.
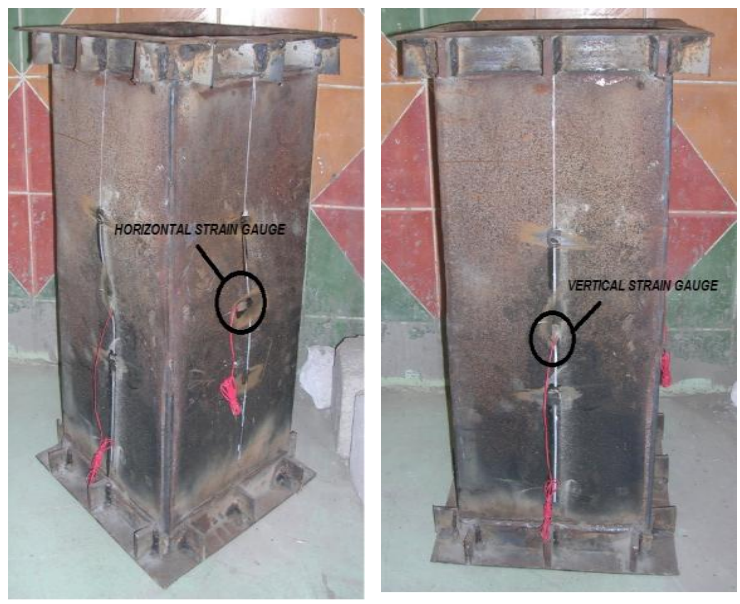

Fig. 3.c Strain gauges

\section{RESULT OF THE STUDY}

The results of the experimental study will be discussed focusing the observed different phenomenon.

\subsection{Axial Shortening}

The load-axial shortening behaviour provides information on the maximum load and apparent ductility of each specimen. The load-axial shortening results for each series of tests compared in Fig.(4) for the hollow, normal strength concrete-infill and high strength concrete-infill box sections, respectively. These results for hollow columns is actually the average of LVDT1, 2, 3 and 4 but for normal strength concrete-infill and high strength concrete-infill columns, the average of LVDT1 and LVDT2.

The diagrams show that the stiffness and strength of filled sections is significantly greater than those for the hollow sections of the same dimensions, particularly for the cases of (b/t) (50 and 66.67). When the slenderness values of (b/t) (83.33 and 100) are considered, there is no or little effect. Also these diagrams show that the stiffness and strength of high strength concrete-filled sections is significantly greater than those for normal concrete filled sections of the same dimensions for the case of (b/t) (41.67) and there is no difference for the other cases. The axial stiffness doesn't seem to vary, since local buckling occurs very early. In these specimens the main purpose of the concrete is to increase the post buckling strength of the steel Short columns.

\subsection{1 load-axial shortening of specimens}

\section{(H1, FN1 and FH1)}

the specimen $\mathrm{H} 1$ at the experimental test reached to deflection of $(1.9 \mathrm{~mm})$ at load $(250 \mathrm{kN})$ and deflection of $(2.7 \mathrm{~mm})$ at the failure load of $(280 \mathrm{kN})$ where the specimen FN-1 at the experimental test reached to deflection of $(1.2 \mathrm{~mm})$ at load $(256 \mathrm{kN})$ then $(1.8 \mathrm{~mm})$ at the failure load of $(293 \mathrm{kN})$, and the specimen $\mathrm{FH}-1$ at 
the experimental test reached to deflection of $(2.35 \mathrm{~mm})$ at load of $(330 \mathrm{kN})$ then $(2.8)$ at the failure load of (333 $\mathrm{kN})$.

\subsection{2 load-axial shortening of specimens}

\section{(H2 and FN2)}

The specimen $\mathrm{H} 2$ reached to deflection off $(1.6 \mathrm{~mm})$ at load $(220 \mathrm{kN})$ then $(3.5 \mathrm{~mm})$ at the failure load of $(300 \mathrm{kN})$ where the specimen $\mathrm{FN}-2$ reached to deflection of $(1.8 \mathrm{~mm})$ at load of $(420 \mathrm{kN})$ then $(2.5 \mathrm{~mm})$ at the failure load of $(450 \mathrm{KN})$.

\subsection{3 load-axial shortening of specimens (H3,FN3 and FH2)}

the specimen $\mathrm{H} 3$ at the experimental test reached to deflection of $(2.5 \mathrm{~mm})$ at load of $(385 \mathrm{kN})$ then $(3.1 \mathrm{~mm})$ at the failure load of $(439 \mathrm{kN})$ where the specimen $\mathrm{FN}-3$ reached to deflection $(2.4 \mathrm{~mm})$ at load of $(385 \mathrm{kN})$ then $(3.5 \mathrm{~mm})$ at the failure load of $(439 \mathrm{kN})$, and the specimen FH-3 at the experimental test reached to deflection of $(1.6 \mathrm{~mm})$ at load of $(422 \mathrm{kN})$ then $(1.87 \mathrm{~mm})$ at the failure load of $(443 \mathrm{kN})$.

\subsection{4 load-axial shortening of specimens (H4 and FN4)}

The specimen $\mathrm{H} 4$ reached to deflection of $(2.3 \mathrm{~mm})$ at $(293 \mathrm{kN})$ then $(2.81)$ at the failure load of $(333 \mathrm{kN})$ where the specimen FN-4 reached to deflection of $(1.75 \mathrm{~mm})$ at $(330 \mathrm{kN})$ then $(2.5 \mathrm{~mm})$ at the failure load of $(365 \mathrm{kN})$.

\subsection{5 load-axial shortening of specimens}

\section{(H5, FN5, and FH3)}

the specimen $\mathrm{H} 5$ reached to deflection of $(2.2 \mathrm{~mm})$ at $(275 \mathrm{kN})$ then $(2.6 \mathrm{~mm})$ at the failure load of $(296 \mathrm{kN})$ where the specimen $\mathrm{FN}-5$ reached to deflection of $(0.7 \mathrm{~mm})$ at $(348 \mathrm{kN})$ then $(1 \mathrm{~mm})$ at the failure load of $(388 \mathrm{kN})$, and the specimen $\mathrm{FH}-3$ reached to deflection of $(0.47 \mathrm{~mm})$ at $(348 \mathrm{kN})$ then $(0.78 \mathrm{~mm})$ at the failure load of $(389 \mathrm{kN})$.

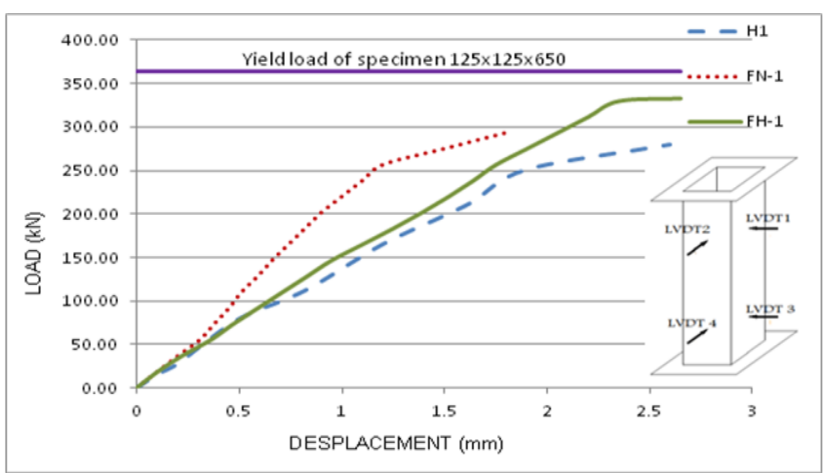

Fig.4.a: load-axial shortening of specimens (H1, FN1 and FH1)

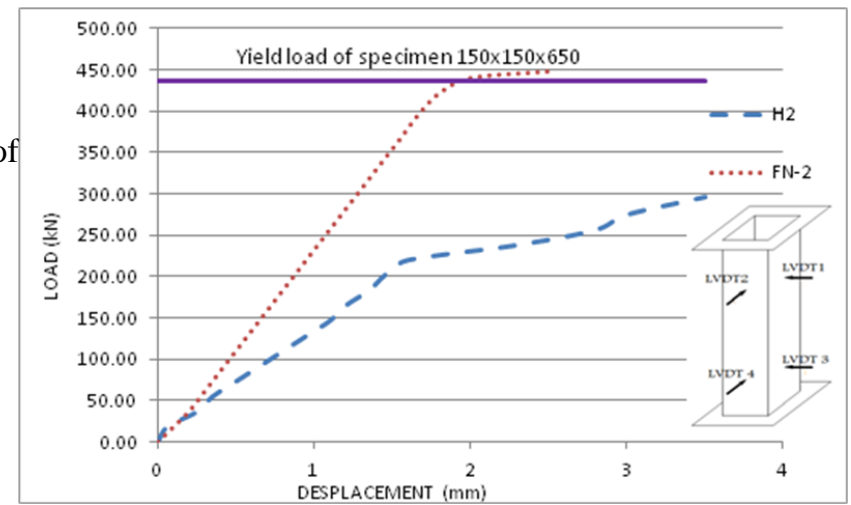

Fig.4.b: load-axial shortening of specimens (H2 and FN2)

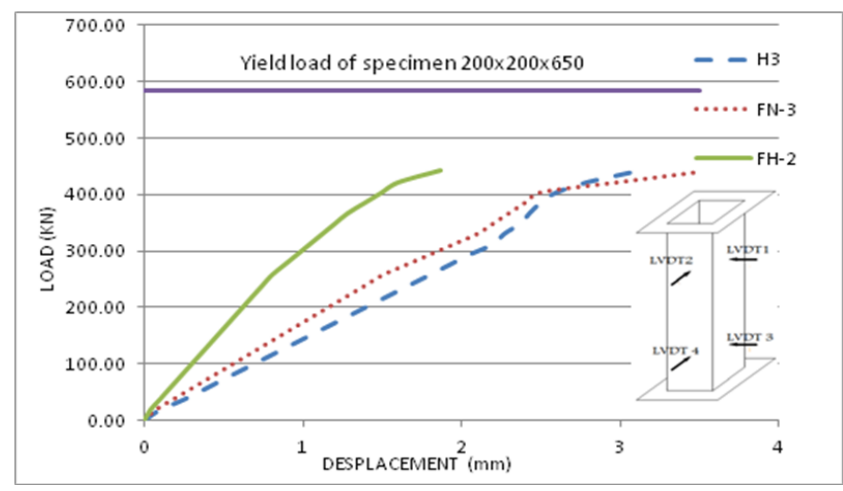

Fig. 4.c:load-axial shortening of specimens (H3,FN3 and FH2)

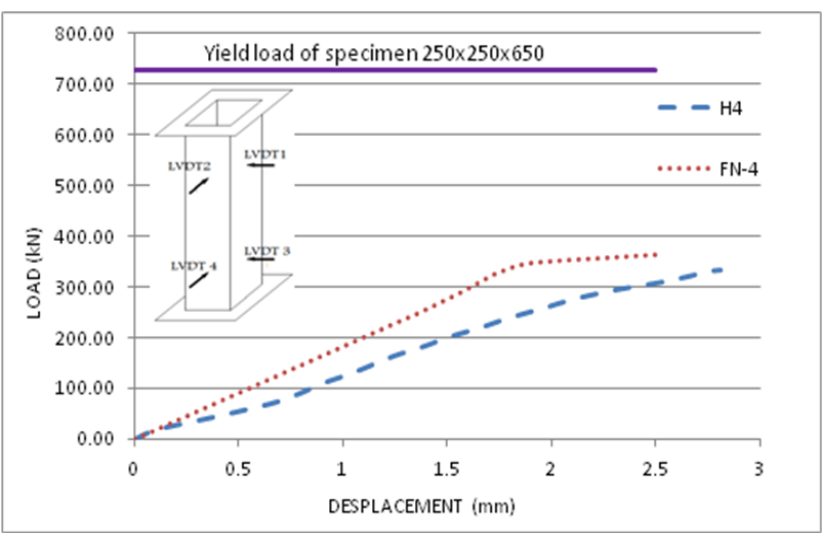

Fig. 4.d:load-axial shortening of specimens (H4 and FN4) 


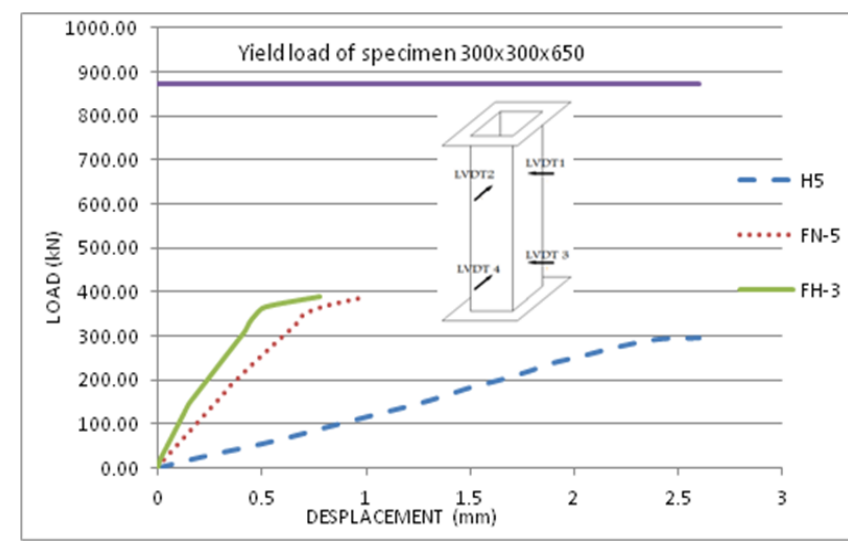

Fig. 4.e: load-axial shortening of specimens (H5, FN5, and FH3)

\begin{tabular}{|c|c|c|c|c|c|}
\hline $\begin{array}{c}\text { spec } \\
\text { ime } \\
n\end{array}$ & $\begin{array}{l}\text { Load } \\
\text { at the } \\
\text { end of } \\
\text { elastic } \\
\text { zone } \\
(\mathrm{kN})\end{array}$ & $\begin{array}{l}\text { Displ } \\
\text { acem } \\
\text { ent } \\
(\mathrm{mm})\end{array}$ & $\begin{array}{c}\text { Failu } \\
\text { re } \\
\text { load } \\
(\mathrm{kN})\end{array}$ & $\begin{array}{c}\text { Displa } \\
\text { cement } \\
(\mathrm{mm})\end{array}$ & $\begin{array}{l}\mathrm{Fi} \\
\text { g. }\end{array}$ \\
\hline H1 & 250 & 1.9 & 280 & 2.7 & 4.a \\
\hline $\begin{array}{c}\text { FN- } \\
1\end{array}$ & 256 & 1.2 & 293 & 1.8 & 4.a \\
\hline $\begin{array}{c}\mathrm{FH}- \\
1\end{array}$ & 330 & 2.35 & 333 & 2.8 & 4.a \\
\hline $\mathrm{H} 2$ & 220 & 1.6 & 300 & 3.5 & 4.b \\
\hline $\begin{array}{c}\text { FN- } \\
2\end{array}$ & 420 & 1.8 & 450 & 2.5 & 4.b \\
\hline H3 & 385 & 2.5 & 439 & 3.1 & 4.c \\
\hline $\begin{array}{c}\text { FN- } \\
3\end{array}$ & 385 & 2.4 & 439 & 3.5 & 4.c \\
\hline $\begin{array}{c}\text { FH- } \\
2\end{array}$ & 422 & 1.6 & 443 & 1.87 & 4.c \\
\hline H4 & 293 & 2.3 & 333 & 2.81 & 4.d \\
\hline $\begin{array}{c}\text { FN- } \\
4\end{array}$ & 330 & 1.75 & 365 & 2.5 & 4.d \\
\hline H5 & 275 & 2.2 & 296 & 2.6 & 4.e \\
\hline $\begin{array}{c}\text { FN- } \\
5\end{array}$ & 348 & 0.7 & 388 & 1 & 4.e \\
\hline $\begin{array}{c}\text { FH- } \\
3\end{array}$ & 348 & 0.47 & 389 & 0.78 & 4.e \\
\hline
\end{tabular}

\subsection{Load-Average strain}

The load-strain curves which monitor the membrane strain provide information on the development of local buckling and the redistribution of stress commonly known as post local buckling. Strain measured across the full width of the columns. The load-strain curves for typical tests are compared and shown in (Fig.5). These diagrams are very useful in determination of the initial local buckling load and stress for each specimen.

\subsection{1 load-strain of specimens}

\section{(H1, FN1 and FH1)}

the strain of Specimen H1 was $4 \mathrm{E}-4$ at $(103 \mathrm{kN})$ then $1.8 \mathrm{E}-3$ at the failure load of $(280 \mathrm{kN})$ where the strain of specimen $\mathrm{FN}-1$ was $6.5 \mathrm{E}-4$ at $(238 \mathrm{kN})$ then $1 \mathrm{E}-3$ at failure load of $(293 \mathrm{kN})$ and the strain of specimen $\mathrm{FH}-1$ was $5.8 \mathrm{E}-4$ at $(275 \mathrm{kN})$ then $8.4 \mathrm{E}-4$ at failure load $(333$ $\mathrm{KN})$.

\subsection{2 load-strain of specimens (H2 and FN2)}

the strain of the specimen $\mathrm{H} 2$ was $1.3 \mathrm{E}-3$ at $(257 \mathrm{kN})$ then 0.002 at the failure load of $(296 \mathrm{kN})$ where the strain of the specimen at $\mathrm{FN}-2$ was $8.8 \mathrm{E}-4$ at $(403 \mathrm{kN})$ then $1.1 \mathrm{E}-3$ at the failure load of $(448 \mathrm{kN})$

\subsection{3 load-strain of specimens (H3,FN3 and FH2)}

the strain of the specimen $\mathrm{H} 3$ was $1.25 \mathrm{E}-3$ at $(385 \mathrm{kN})$ then $1.6 \mathrm{E}-3$ at the failure load of $(439 \mathrm{kN})$ where the strain of the specimen at FN-3 was $5.5 \mathrm{E}-4$ at $(421 \mathrm{kN})$ then $7 \mathrm{E}-4$ at the failure load of $(439 \mathrm{kN})$ and the specimen of $\mathrm{FH}-3$ was $5.28 \mathrm{E}-4$ at $(421 \mathrm{kN})$ then $6.72 \mathrm{E}$ 4 at the failure load of $(443 \mathrm{kN})$.

\subsection{4 load-strain of specimens (H4 and FN4)}

the strain of the specimen was $1 \mathrm{E}-3$ at $(275 \mathrm{kN})$ then $2 \mathrm{E}$ 3 at the failure load of $(333 \mathrm{kN})$ where the strain of the specimen FN-4 was $2.5 \mathrm{E}-4$ at ( $348 \mathrm{kN}$ ) then $4 \mathrm{E}-4$ at failure load of $(365 \mathrm{kN})$. there was a drop at the curve at load of $(238 \mathrm{kN})$ due to a mistake at the data reading and collection.

\subsection{5 load-strain of specimens}

\section{(H5, FN5 and FH3)}

The strain of the specimen $\mathrm{H} 5$ was $7.7 \mathrm{E}-4$ at $(275 \mathrm{kN})$ then $1.1 \mathrm{E}-3$ at the failure load of $(296 \mathrm{kN})$ where the stain of the specimen $\mathrm{FN}-5$ was $1.99 \mathrm{E}-4$ at $(348 \mathrm{kN})$ then $4.02 \mathrm{E}-4$ at failure load of $(388 \mathrm{kN})$ and the strain of the specimen FH-5 was 2.1E-4 at $(348 \mathrm{kN})$ then $4 \mathrm{E}-4$ at the failure load of $(390 \mathrm{kN})$. 


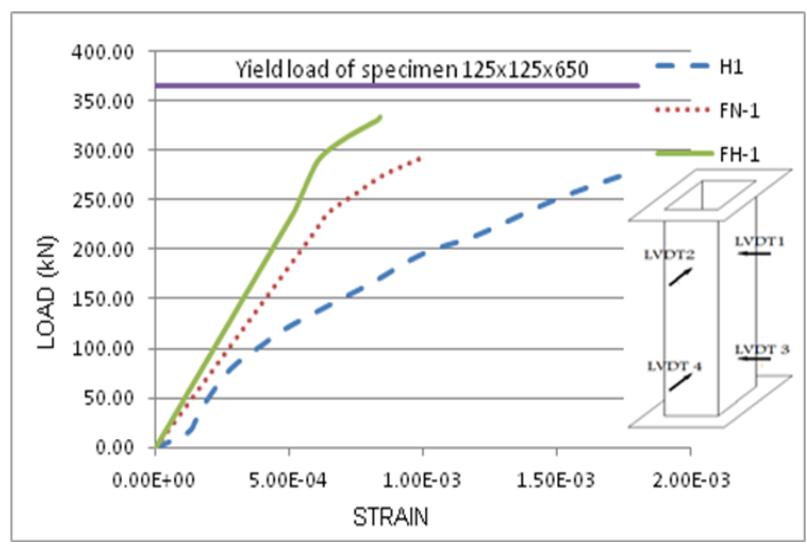

Fig.5.a :load-strain of specimens (H1,FN1 and FH1)

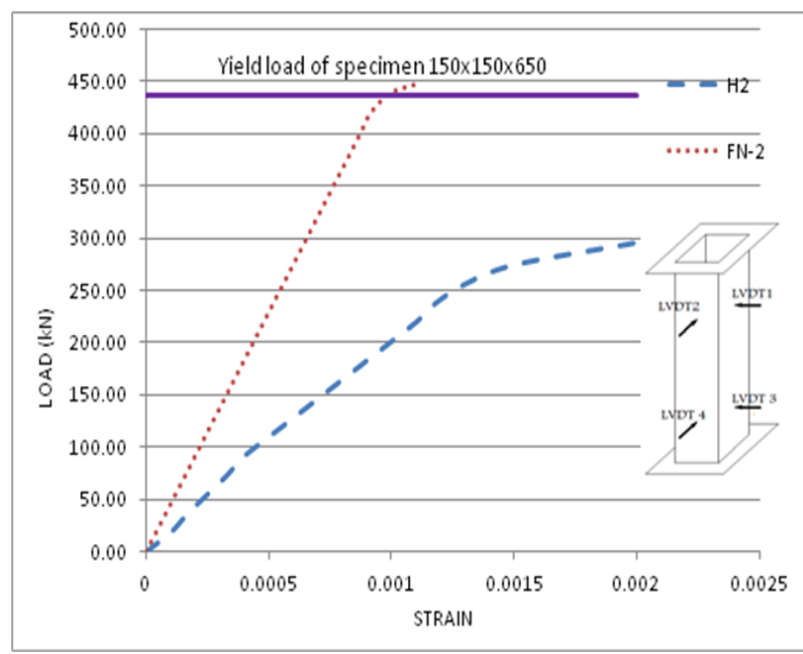

Fig.5.b : load-strain of specimens (H2 and FN2)

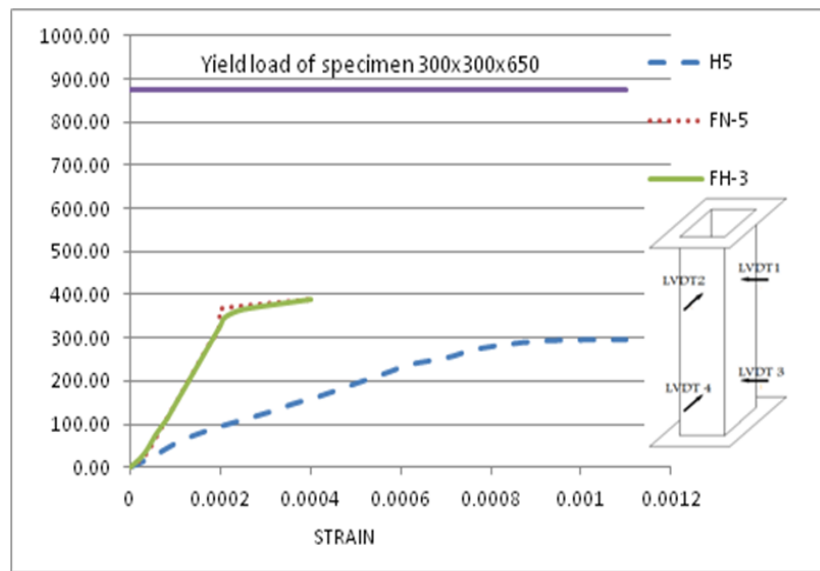

Fig. 5.c :load-strain of specimens (H3,FN3 and FH2)

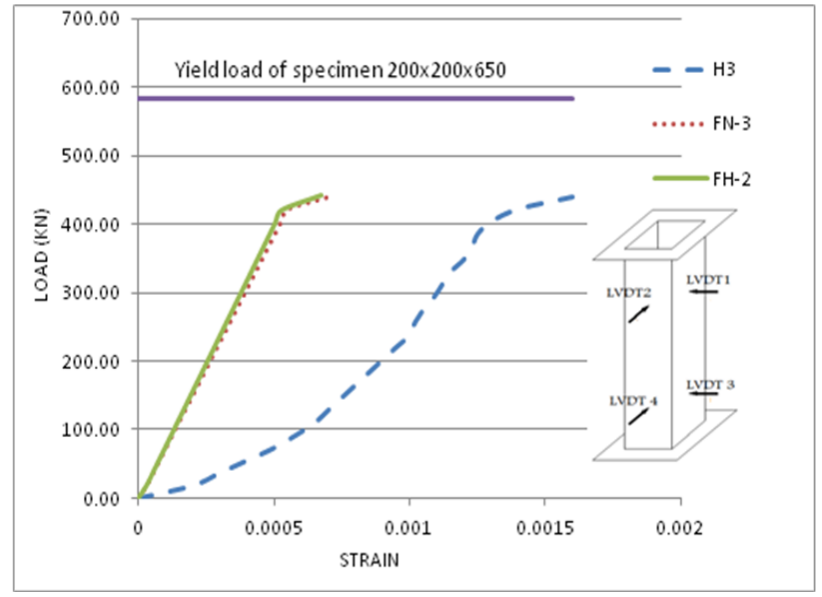

Fig.5.d :load-strain of specimens (H4 and FN4)

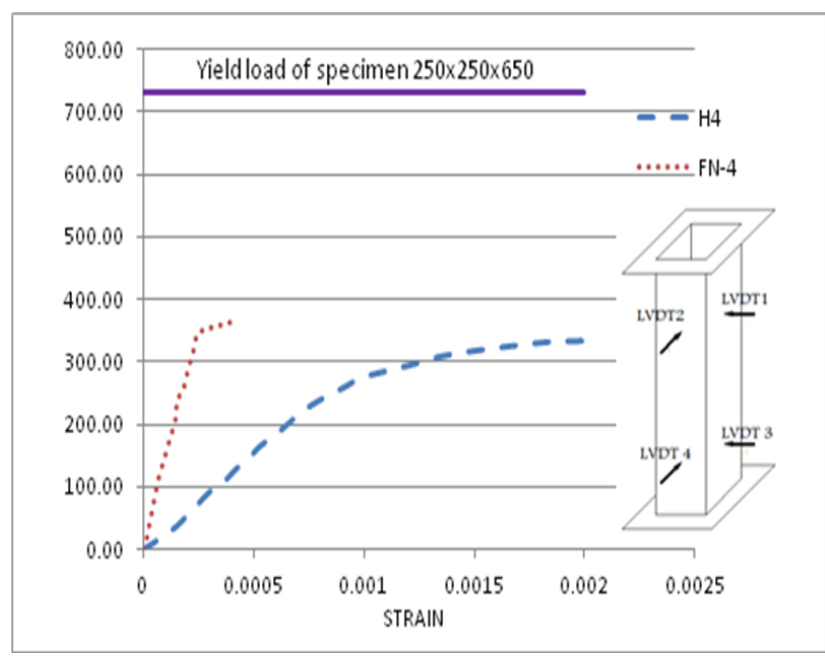

Fig.5.e: load-strain of specimens (H5, FN5 and FH3)

\begin{tabular}{|c|c|c|c|c|c|}
\hline speci & $\begin{array}{c}\text { Load } \\
\text { at the } \\
\text { end of } \\
\text { elastic } \\
\text { zone } \\
(\mathrm{kN})\end{array}$ & Strain & $\begin{array}{c}\text { Failu } \\
\text { re } \\
\text { load } \\
(\mathrm{kN})\end{array}$ & Strain & Fig \\
\hline H1 & 103 & $4 \mathrm{E}-4$ & 280 & $\begin{array}{c}1.8 \mathrm{E}- \\
03\end{array}$ & $5 . \mathrm{a}$ \\
\hline FN-1 & 238 & $6.5 \mathrm{E}-4$ & 293 & $1 \mathrm{E}-3$ & $5 . \mathrm{a}$ \\
\hline FH-1 & 275 & $5.8 \mathrm{E}-4$ & 333 & $8.4 \mathrm{E}-4$ & $5 . \mathrm{a}$ \\
\hline H2 & 257 & $1.3 \mathrm{E}-3$ & 296 & 0.002 & $5 . \mathrm{b}$ \\
\hline FN-2 & 403 & $8.8 \mathrm{E}-4$ & 448 & $1.1 \mathrm{E}-3$ & $5 . \mathrm{b}$ \\
\hline H3 & 385 & $1.25 \mathrm{E}-$ & 439 & $1.6 \mathrm{E}-3$ & $5 . \mathrm{c}$ \\
\hline FN-3 & 421 & $5.5 \mathrm{E}-4$ & 439 & $7 \mathrm{E}-4$ & $5 . \mathrm{c}$ \\
\hline FH-2 & 421 & $\begin{array}{c}5.28 \mathrm{E}- \\
4\end{array}$ & 443 & $6.72 \mathrm{E}-$ & $5 . \mathrm{c}$ \\
\hline H4 & 275 & $1 \mathrm{E}-3$ & 333 & $2 \mathrm{E}-3$ & $5 . \mathrm{d}$ \\
\hline FN-4 & 348 & $2.5 \mathrm{E}-4$ & 365 & $4 \mathrm{E}-4$ & $5 . \mathrm{d}$ \\
\hline H5 & 275 & $7.7 \mathrm{E}-4$ & 296 & $1.1 \mathrm{E}-3$ & $5 . \mathrm{e}$ \\
\hline FN-5 & 348 & $1.99 \mathrm{E}-$ & 388 & $4.02 \mathrm{E}-$ & $5 . \mathrm{e}$ \\
\hline
\end{tabular}

112 


\begin{tabular}{|c|c|c|c|c|c|}
\hline & & 4 & & 4 & \\
\hline FH-3 & 348 & $2.1 \mathrm{E}-4$ & 390 & $4 \mathrm{E}-4$ & $5 . \mathrm{e}$ \\
\hline
\end{tabular}

\subsection{Failure Modes}

Typical failure modes of hollow, normal concreteinfill and high strength concrete-infill box sections are illustrated in Fig.(6). One should note that the local buckling half wave-lengths for hollow sections are considerably larger than those for the normal concrete-filled sections and the both types are larger than those of high strength concretefilled sections. The failure modes illustrated in Fig.(6) Highlight how the end stiffeners have forced the buckle into the central regions of specimens and thus where the concrete restraint is present. Fig.(6) shows the failure modes of all specimens.
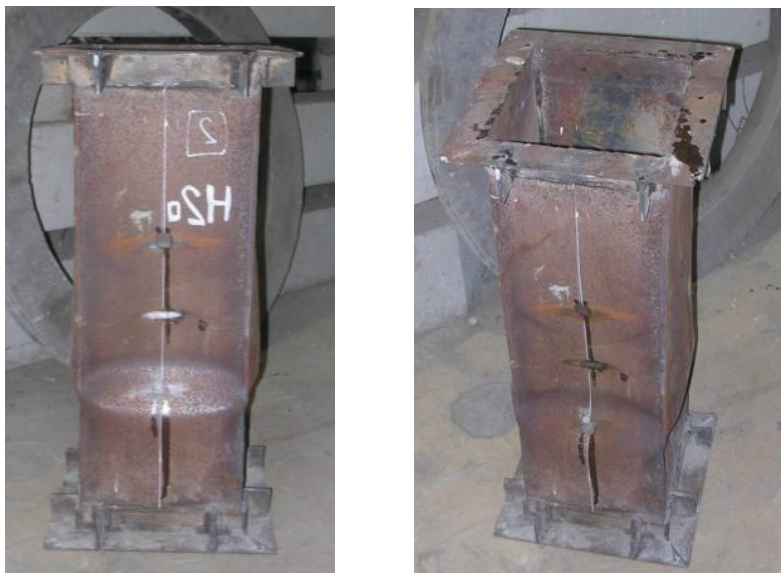

Fig.6.1: failure modes of specimens (Group A)
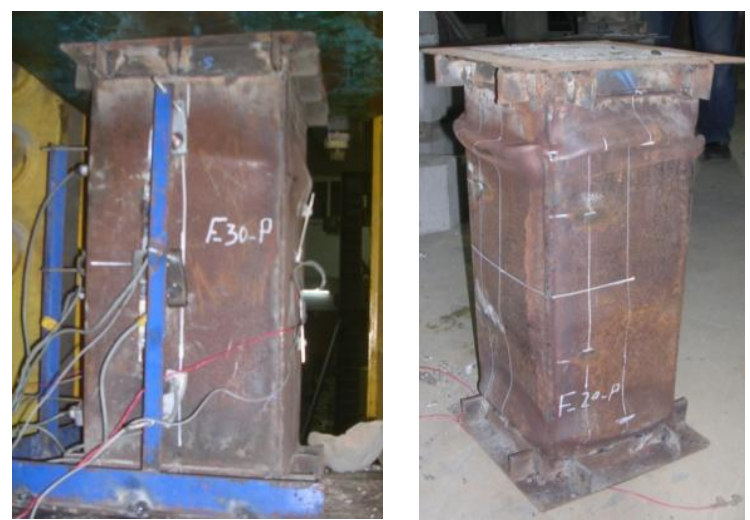

Fig.6.2: failure modes of specimens (Group B)

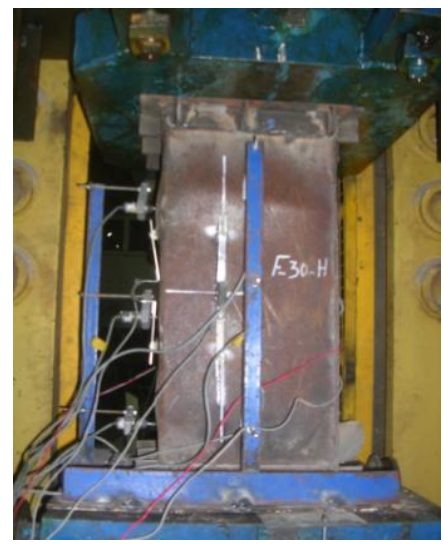

Fig.6.3: failure modes of specimens (Group C)

\section{DISCUSSION}

The results of experimental results carried out on short columns have been presented to investigate how different depth-to-thickness (slenderness ratio) affects the response of the steel component.

Table (3) shows the failure loads for each specimen $(\mathrm{KN})$ also the corresponding displacement ( $\mathrm{mm}$ ).

Table (3) the failure loads for each specimen (KN) also the corresponding displacement (mm).

\begin{tabular}{|c|c|c|c|c|}
\hline \multirow{4}{*}{ Group } & $\begin{array}{c}\text { Speci } \\
\text { men } \\
\text { name }\end{array}$ & $\mathrm{b} / \mathrm{t}$ & $\begin{array}{c}\text { Failure } \\
\text { Load } \\
(\mathrm{kN})\end{array}$ & $\begin{array}{c}\text { Displac } \\
- \text { ement } \\
\text { mm }\end{array}$ \\
\hline \multirow{4}{*}{ A } & H1 & 41.67 & 457 & 2.7 \\
\cline { 2 - 5 } & $\mathrm{H} 2$ & 50.00 & 485 & 3.5 \\
\cline { 2 - 5 } & $\mathrm{H} 3$ & 66.67 & 719 & 3.1 \\
\cline { 2 - 5 } & H4 & 83.33 & 545 & 2.81 \\
\cline { 2 - 5 } & H5 & 100 & 485 & 2.6 \\
\hline \multirow{4}{*}{ B } & F-N1 & 41.67 & 480.5 & 1.8 \\
\cline { 2 - 5 } & F-N2 & 50.00 & 733 & 2.5 \\
\cline { 2 - 5 } & F-N3 & 66.67 & 719 & 3.5 \\
\cline { 2 - 5 } & F-N4 & 83.33 & 597 & 2.5 \\
\cline { 2 - 5 } & F-N5 & 100 & 635 & 1 \\
\hline \multirow{4}{*}{ C } & F-H1 & 41.67 & 550 & 2.8 \\
\cline { 2 - 5 } & F-H2 & 66.67 & 725 & 1.87 \\
\cline { 2 - 5 } & F-H3 & 100 & 638 & 0.78 \\
\hline
\end{tabular}

From the result its could be found that specimen $\mathrm{H} 1$ had a geometric failure, where by using concrete in-fill the failure became a material failure, as the load at the end of elastic zone of specimen $\mathrm{H} 1$ was $250 \mathrm{kN}$ where it was $330 \mathrm{kN}$ for specimen $\mathrm{FH} 1$ and the yield load is $364.5 \mathrm{kN}$, Fig.4.a. Also specimen $\mathrm{H} 2$; the load at the end of elastic zone of specimen $\mathrm{H} 2$ was $275 \mathrm{kN}$ where it was 
$440 \mathrm{kN}$ for specimen FN2 and the yield load is $437 \mathrm{kN}$, Fig.4.b.

Other Specimens had a geometric failure as their load at the end of elastic zone is more less than the yeild load. As the load at the end of elastic zone of specimen $\mathrm{H} 3$ ,FN3 and FH2 was $422 \mathrm{kN}$ where the yield load is $583.2 \mathrm{kN}$, Fig.4.c. the load at the end of elastic zone of specimen $\mathrm{H} 4$ was $275 \mathrm{kN}$ where it was $348 \mathrm{kN}$ for specimen FH4 and the yield load is $729 \mathrm{kN}$,Fig.4.d. the load at the end of elastic zone of specimen H5 ,FN5 and $\mathrm{FH} 3$ was $300 \mathrm{kN}, 348 \mathrm{kN}$ and $366 \mathrm{kN}$ respectively where the yield load is $874.8 \mathrm{kN}$, Fig.4.e.

\section{CONCLUSSION}

Based on this, the present work has led to the following conclusions:

1-Increasing in-fill concrete compressive strength has no or little effect on axial column load capacity, especially in high slenderness ratio of steel wall (b/t) of columns.

2-The effects of local buckling can be ignored in the calculation of the contribution of the columns for relative depth-to-thickness ratios less than 60 . For higher ratios, local buckling needs to be considered in the design

3-The bearing capacity of steel tubes filled with concrete is evidently higher than the one of hollow steel columns when the relative depth-to-thickNess ratio is greater than 60.

4-The effect of materials strengths by changing grade of reinforced concrete is shown obviously in concrete-filled columns for slenderness ratios less than 60 .

\section{REFERENCES}

[1] AISC (2005). Specification for Structural Steel Buildings, American Institute of Steel Construction, Chicago, IL

[2] American Concrete Institute. Building Code requirements for Structural Concrete (ACI 318R02). Detroit;2002

[3] American Institute of Steel Construction. Manual of Steel construction: Load and resistance factor design $3^{\text {rd }}$ ed. Chicago (IL): AISC;2001

[4] Buildings Code Requirements for Structural Concrete (ACI 318-99). Detroit (MI): American Concrete Institute (ACI), 1999

[5] Local and post local buckling of concrete filled steel welded box columns; B. uy, (1998) 47-72.

[6] Experimental behaviour of stiffened concretefilled thin-walled hollow steel structure (HSS) stub columns ; Zhong Taob, Lin-Haihan, Zhi-Bin Wang (2005) 962-983

[7] Experimental behaviour of high performance concrete-filled steel tubular columns ;Qing Yua, Zhong Taob, Ying-Xing Wu, (2007)

[8] Test on high-strength rectangular concrete-filled steel hollow section stub columns; Dalin Liu' (2005) 902-911

[9] Strength of Concrete Filled Steel Tubular Columns; Muhammad Naseem Baig (2005)
[10] Behaviour of thin walled steel tube confined concrete stub columns subjected to axial local compression Lin-Hai Han, Wei Liub, You-Fu Yang, (2007)

[11] Behaviour of normal and high strength concretefilled compact steel tube circular stub columns; Ehab Ellobodya, Ben Youngb, Dennis Lam, (2005).

[12] Experimental and computational study of concrete filled steel tubular columns under axial loads; P.K. Gupta, S.M. Sarda, M.S. Kumar, (2006).

[13] A compative Experimental study between stiffned and un stiffnedstainless steel hallow tubular stub column, thin-walled structure 47, (2009) 73-81; M.A.Dabaon, M.H. El-Baghdadi, M.F.Hassanein.

[14] Expermental investigation on concrete-filled stainless steel stiffened tubular stub columns, Engineering structure 31 (2009) 300-307; M.A.Dabaon, M.H. El-Baghdadi, M.F.Hassanein.

\section{AKNOWLEDGEMENT}

Special thanks to Housing and Building National

Research Center, the concrete research laboratory. 